\title{
The expression of transforming growth factor $\beta$ in pregnant rat myometrium is hormone and stretch dependent
}

\author{
Oksana Shynlova ${ }^{1}$, Prudence Tsui ${ }^{1,2}$, Anna Dorogin ${ }^{1}$, B Lowell Langille ${ }^{4}$ and Stephen J Lye $\mathrm{e}^{1,2,3}$ \\ ${ }^{1}$ Samuel Lunenfeld Research Institute at Mount Sinai, Mount Sinai Hospital, 600 University Avenue, Suite 870, \\ Toronto, Ontario, Canada M5G 1X5, Departments of ${ }^{2}$ Physiology and ${ }^{3}$ Obstetrics and Gynecology, University of \\ Toronto, Toronto, Canada M5S 1A1 and ${ }^{4}$ Toronto General Research Institute, University Health Network, Toronto, \\ Canada M5G 2C4
}

Correspondence should be addressed to S J Lye; Email: lye@mshri.on.ca

O Shynlova and P Tsui contributed equally to this work

\begin{abstract}
From a quiescent state in early pregnancy to a highly contractile state in labor, the myometrium displays tremendous growth and remodeling. We hypothesize that the transforming growth factor $\beta$ (TGF $\beta$ ) system is involved in the differentiation of pregnant myometrium throughout gestation and labor. Furthermore, we propose that during pregnancy the mechanical and hormonal stimuli play a role in regulating myometrial TGF $\beta$ s. The expression of TGF $\beta 1-3$ mRNAs and proteins was examined by real-time PCR, Western immunoblot, and localized with immunohistochemistry in the rat uterus throughout pregnancy and labor. Tgf $\beta$ 1-3 genes were expressed differentially in pregnant myometrium. Tgf $\beta 2$ gene was not affected by pregnancy, whereas the $\operatorname{Tg} f \beta 1$ gene showed a threefold increase during the second half of gestation. In contrast, we observed a dramatic bimodal change in Tgf $\beta 3$ gene expression throughout pregnancy. Tgf $\beta 3 \mathrm{mRNA}$ levels first transiently increased at mid-gestation (11-fold on day 14) and later at term (45-fold at labor, day 23). Protein expression levels paralleled the changes in mRNA. Treatment of pregnant rats with the progesterone (P4) receptor antagonist RU486 induced premature labor on day 19 and increased Tgf $\beta 3 \mathrm{mRNA}$, whereas artificial maintenance of elevated P4 levels at late gestation (days 20-23) caused a significant decrease in the expression of $\operatorname{Tg} f \beta 3$ gene. In addition, $T g f \beta 3$ was up-regulated specifically in the gravid horn of unilaterally pregnant rats subjected to a passive biological stretch imposed by the growing fetuses, but not in the empty horn. Collectively, these data indicate that the TGF $\beta$ family contributes in the regulation of myometrial activation at term integrating mechanical and endocrine signals for successful labor contraction.

Reproduction (2007) 134 503-511
\end{abstract}

\section{Introduction}

The transforming growth factor $\beta$ (TGF $\beta$ ) superfamily is composed of five related peptides, three of which are found in mammalian tissues, namely TGF $\beta 1$, TGF $\beta 2$, and TGF $\beta 3$ (Massague et al. 1994). They exert their actions via three receptors: type I, type II, and type III (Massague et al. 1994). The intracellular signaling cascade linking TGF $\beta$ family ligands and TGF $\beta$ receptors to a cellular response is extremely complex and includes a large group of SMAD proteins carrying signals from the cell surface directly to the nucleus (Attisano \& Wrana 2002). TGF $\beta$ isoforms have been studied extensively in the reproductive system. They are multifunctional growth factors expressed by fetoplacental, cervical, and uterine tissues, where they regulate (1) cellular proliferation, (2) tissue remodeling, and (3) inflammatory response (Barnard et al. 1990, Lawrence 1996). The
mRNA of all three TGF $\beta$ isoforms is present in human term placenta in the syncytiotrophoblastic layer, chorionic plate, and in cells of the extravillous trophoblast (Schilling \& Yeh 2000). TGF $\beta$ s were amongst the first identified regulators of invasive trophoblast differentiation since they inhibited the proliferation of first trimester cytotrophoblasts (Graham et al. 1992). Furthermore, TGF $\beta$ s exert anti-invasive effects on trophoblasts by increasing tissue inhibitor of matrix metalloproteinase (TIMP) expression and blocking matrix metalloproteinase (MMP) activity (Graham \& Lala 1991, Ma \& Chegini 1999). In placental trophoblasts and myometrial smooth muscle cells (SMCs), TGF $\beta$ has been shown to up-regulate the expression of fibronectin, a marker of preterm labor (Goldenberg et al. 1997, Chegini et al. 1999). TGF $\beta$ s mRNA and proteins are expressed in the human myometrium during menstrual cycle (Chegini et al. 1994) and pregnancy (Chegini et al. 1999, Kuscu 
et al. 2001), and have been suggested to play a central role regulating excitability and contractility in the human myometrium at term (Hatthachote \& Gillespie 1999).

We proposed earlier that the ability of the myometrium to contract at term can be defined biochemically as an increase in expression of a cassette of genes encoding 'contraction-associated proteins' (CAPs), which control the contractile activity and responsiveness of the myometrium during labor (Challis 1994). We have shown that the timely expression of putative CAPs (Cx43, oxytocin receptor, prostaglandin receptor) is regulated by the integration of fetal endocrine and growth signals underlying myometrial activation $(\mathrm{Ou}$ et al. 1997, 1998). In addition, we have reported that the activation of CAP genes at term correlated with the increase in extracellular matrix (ECM) protein expression (Shynlova et al. 2004). It has been reported by others that the CAP and ECM expression could be regulated by cytokines, such as TGF $\beta 1$, which may play a role in preparing the myometrium for parturition (Hatthachote et al. 1998). There is an evidence for the involvement of other cytokines in the modulation of myometrial function. Specifically, pro-inflammatory cytokines increase in human myometrium at term, suggesting that a cascade of cytokine interactions might prepare the myometrium for spontaneous preterm or term labor (Romero et al. 1991, 2006).

While several studies have reported the immunolocalization of TGF $\beta$ s and their receptors in pregnant term and preterm human myometrium (Hatthachote et al. 1998, Chegini et al. 1999, Kuscu et al. 2001), very limited information is available on the expression of TGF $\beta$ ligands and their function throughout pregnancy. We hypothesized that cytokines, specifically TGF $\beta \mathrm{s}$, may assist in the myometrial activation at labor by mediating changes in pregnant uterine smooth muscle during consecutive phases of myometrial differentiation (Shynlova et al. 2006). We further proposed that mechanical and hormonal stimuli might regulate the expression of TGF $\beta$ s in pregnant myometrium. In this study, we defined the expression profile of TGF $\beta 1-3$ in the rat myometrium during normal pregnancy, spontaneous term labor, and post partum using real-time PCR, immunoblotting, and immunohistology techniques. We also investigated the effect of progesterone (P4) on the expression of Tgf $\beta 3$ gene using a P4-delayed labor and RU486-induced preterm labor models. In addition, the effect of gravidity on the expression and localization of TGF $\beta 3$ was investigated using a unilateral tubal-ligation rat model.

\section{Materials and Methods}

\section{Animals}

Wistar rats (Charles River Co., St Constance, Canada) were housed individually under standard environmental conditions (12 h light:12 h darkness cycle) and fed Purina Rat Chow (Ralston Purina, St Louis, MO, USA) and water ad libitum. Female virgin rats were mated with male rats. Day 1 of gestation was designated as the day a vaginal plug was observed. The average time of delivery under these conditions was during the morning of day 23. Our criteria for labor were based on delivery of at least one pup. The Samuel Lunenfeld Research Institute Animal Care Committee approved all animal experiments.

\section{Experimental design}

\section{Normal pregnancy and term labor}

Animals were killed by carbon dioxide inhalation and myometrial samples were collected on gestational days 0 (non-pregnant, NP), 6, 8, 10, 12, 14, 15, 17, $19,21,22,23$ (labor), or 1 and 4 day post partum (PP). Tissue was collected at $1200 \mathrm{~h}$ on all days with the exceptions of the labor sample (day 23L) that was collected once the animals had delivered at least one pup $(n=4)$.

\section{P4-delayed labor}

To determine whether high plasma levels of $\mathrm{P} 4$ might modulate the expression of TGF $\beta$ family genes, pregnant rats were randomized to receive daily s.c. injections of either P4 (medroxyprogesterone acetate, $16 \mathrm{mg} / \mathrm{kg}$ in $0.4 \mathrm{ml}$ sterile saline, Pharmacia Canada Inc.) or vehicle starting on day 20 of gestation. Animals ( $n=4$ at each time point for each treatment) were killed on days 21 , 22 , or $23 \mathrm{~L}$ in the vehicle-treated group or days 21,22 , 23 , or 24 in the P4-treated group.

\section{RU486-induced preterm labor}

On day 19 of gestation two groups of rats were treated with either RU486 $(10 \mathrm{mg} / \mathrm{kg}$, s.c., at $1000 \mathrm{~h}$, in $0.5 \mathrm{ml}$ corn oil containing $10 \% \mathrm{EtOH}$, Mifepristone; $17 \beta$ hydroxy-11 $\beta$-[4-dimethylaminophenyl]-17-[1-propynyl]-estra-4,10-dien-3-one; Biomol International, Plymouth Meeting, PA, USA) or vehicle. Myometrial samples were collected from both groups of animals on day 20 when the RU486-treated animals had delivered at least one pup $(n=4)$.

\section{Unilaterally pregnant rats}

Under general anesthesia virgin female rats underwent tubal ligation through a flank incision to ensure that they subsequently became pregnant in only one horn (Ou et al. 1998). Animals were allowed to recover from surgery for at least 7 days before mating. Pregnant myometrial samples from empty and gravid horns were collected on days $6,12,14,15,17,19,21,22,23$, or $1 \mathrm{PP}(n=4)$. 


\section{Tissue collection}

Animals were killed by carbon dioxide inhalation. For RNA and protein extraction the uterine horns were placed into ice-cold PBS, bisected longitudinally, and dissected away from both pups and placentas. The endometrium was carefully removed from the myometrial tissue by mechanical scraping on ice, which we have previously shown removes the entire luminal epithelium and the majority of the uterine stroma (Piersanti \& Lye 1995). The myometrial tissue and decidua were flash-frozen in liquid nitrogen and stored at $-70^{\circ} \mathrm{C}$. For immunohistochemical studies the intact uterine horns were placed in ice-cold PBS and fixed immediately in $4 \%$ paraformaldehyde solution at $4{ }^{\circ} \mathrm{C}$ for 48 hours. For each day of gestation, tissue was collected from four different animals.

\section{Real-time-PCR analysis}

Total RNA was extracted from the frozen tissues using TRIZOL (Gibco BRL) according to manufacturer's instructions. RNA samples were column purified using RNeasy Mini Kit (Qiagen), and treated with $2.5 \mu \mathrm{l}$ DNase I (2.73Kunitz unit/ $\mu$, Qiagen) to remove genomic DNA contamination. RT and real-time PCR (RT-PCR) was performed to detect the mRNA expression of TGF $\beta$ s and TGF $\beta$-related genes in rat myometrium. Total RNA $(2 \mu \mathrm{g})$ was primed with random hexamers to synthesize singlestrand cDNAs in a total reaction volume of $100 \mu \mathrm{l}$ using the TaqMan RT Kit (Applied Biosystems, Foster City, CA, USA) as described earlier (Shynlova et al. 2005). cDNA (20 ng) from the previous step was subjected to real-time PCR using specific sets of primers (see legend to Fig. 1) in a total reaction volume of $25 \mu \mathrm{l}$ (Applied Biosystems). RT-PCR was performed in an optical 96-well plate with an ABI PRISM 7900 HT Sequence Detection System (Applied Biosystems), using the SYBR Green detection chemistry. The run protocol was as follows: initial denaturation stage at $95^{\circ} \mathrm{C}$ for $10 \mathrm{~min}, 40$ cycles of amplification at $95^{\circ} \mathrm{C}$ for $15 \mathrm{~s}$ and $60^{\circ} \mathrm{C}$ for $1 \mathrm{~min}$. After PCR, a dissociation curve was constructed by increasing temperature from 65 to $95^{\circ} \mathrm{C}$ for detection of PCR product specificity. In addition, a no-template control $\left(\mathrm{H}_{2} \mathrm{O}\right.$ control) was analyzed for possible contamination in the master-mix. A cycle threshold $(\mathrm{Ct})$ value was recorded for each sample. PCRs were set up in triplicates and the mean of the three Cts was calculated. A comparative Ct method ( $\Delta \Delta \mathrm{Ct}$ method) was applied to the raw $\mathrm{Ct}$ values to find a relative gene expression across normal gestation. To obtain experimental results, the expression of individual gene at every gestational day (1) was normalized to ribosomal 18S mRNA and (2) a fold change was calculated relative to the expression of the same gene in corresponding NP sample using an arithmetic formula (see $A B I$ User Bulletin \#2). For unilaterally pregnant animals, the gene expression was
A
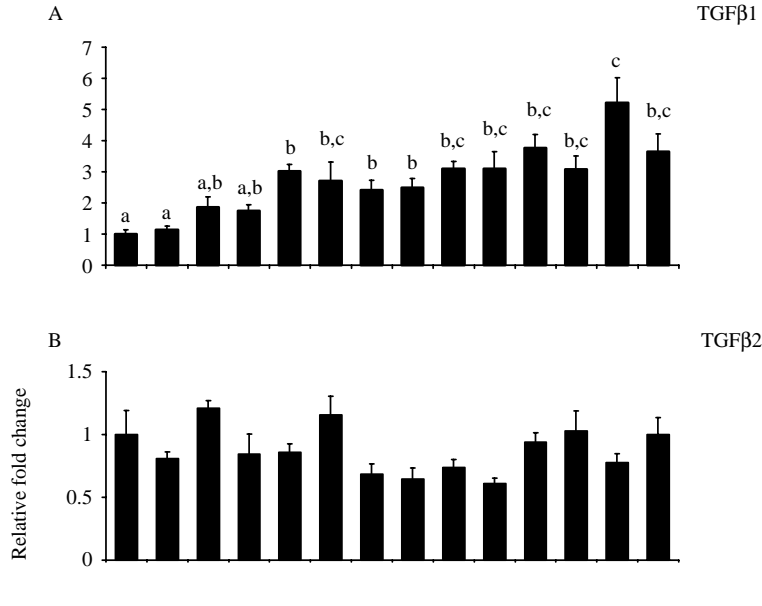

C

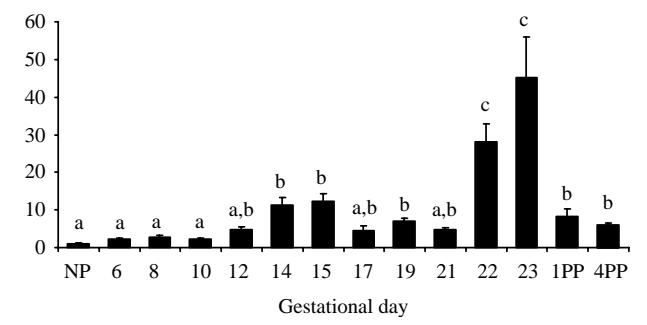

Figure 1 The effects of gestational age on the expression of TGFb1-3 genes in the pregnant rat myometrium. Total RNAs were extracted from frozen myometrial tissues, single-strand cDNAs were synthesized as described under 'Materials and Methods' and mRNA levels were analyzed on the indicated days of gestation by real-time PCR. Specific forward and reverse primers were designed using Primer Express software, version 2.0.0 (Applied Biosystems) as follows: TGFb1 mRNA, 5'-AGAAGTCACCCGCGTGCTAAT-3' (sense primer) and 5'-CACTGCTTCCCGAATGTCTGA-3' (antisense primer; GenBank accession \#: NM_021578); TGFb2 mRNA, 5'-TTCAGAATCGTCCGCTTCGAT-3' (sense primer) and $5^{\prime}$-TTGTTCAGCCACTCTGGCCTT-3' (antisense primer; GenBank accession \#: NM_031131); TGFB3 mRNA, 5'-ATACAACACCCTGAACCCGGA-3' (sense primer) and 5'-CGACTTCACCACCATGTTGGA-3' (antisense primer; GenBank accession \#: NM_013174); 18S, 5' -GCGAAAGCATTTGCCAAGAA-3' (sense primer) and 5-'GGCATCGTT-

TATGGTCGGAAC-3' (antisense primer; GenBank accession \#: X01117). TGFb1-3 mRNA levels were normalized to $18 \mathrm{~S}$ mRNAs and expressed in fold changes relative to a corresponding nonpregnant sample. The bars represent mean \pm s.D. $(n=4$ at each time point). Data labeled with different letters are significantly different from each other $(P<0.05)$.

shown as fold change relative to day 6 gravid horn mRNA level, whereas that of P4- and RU486-treated animals was shown as a fold change relative to the vehicle sample. Validation experiments were performed to ensure that the PCR efficiencies between the target genes and $18 \mathrm{~S}$ were approximately equal.

\section{Western immunoblot analysis}

Total protein was extracted from the frozen tissues using RIPA lysis buffer as described earlier (Shynlova 
et al. 2005). Protein samples $(40-50 \mu \mathrm{g})$ were resolved by electrophoresis on a $12-15 \%$ SDS-polyacrylamide gel. Proteins were transferred onto polyvinylidene difluoride (PVDF) membrane (Millipore, Bedford, MA, USA) in $25 \mathrm{mM}$ Tris- $\mathrm{HCl}(\mathrm{pH} 8.3), 250 \mathrm{mM}$ glycine, $0.1 \%$ (wt/vol) SDS, for $18 \mathrm{~h}$ at $30 \mathrm{~V}$ and $4{ }^{\circ} \mathrm{C}$. The protein expression levels of TGF $\beta 1$ and TGF $\beta 3$ were measured by western analysis using primary antibody (TGF $\beta 1$ : mouse monoclonal, 1:2000; TGF $\beta 3$ : rabbit polyclonal, 1:2000; Abcam International, Cambridge, CA, USA). PVDF membranes were stripped and reprobed with anti-tubulin (1:3000, clone DM 1A; Sigma-Aldrich) and anti-calponin (1:3000, clone hCP; Sigma) mouse primary antibodies to control the loading variations. Probed membranes were exposed to X-ray film (Kodak XAR, Eastman Kodak) and analyzed by densitometry (Image) software program; National Institutes of Health, Bethesda, MD, USA, http://rsb. info.nih.gov/ij/). Calponin is constitutively expressed in non-pregnant and pregnant rat tissue under the same protein extraction conditions (Williams et al. 2005). Tubulin is present in almost all eukaryotic cells and is commonly used as a housekeeping protein (Vemuganti et al. 2004).

\section{Immunohistochemistry}

The fixed myometrial tissues were sectioned into $10 \mu \mathrm{m}$ thickness and collected on Superfrost Plus slides (Fisher Scientific Ltd., Nepean, ON, Canada). The frozen sections were immersed in $0.3 \%$ hydrogen peroxide (Fisher Scientific, Fair Lawn, NJ, USA). Antigen retrieval was performed by cooking the tissues at $90{ }^{\circ} \mathrm{C}$ after $5 \mathrm{~min}$, followed by blocking with $5 \%$ normal goat serum and incubation with primary antibodies overnight at $4{ }^{\circ} \mathrm{C}$. Primary antibody was rabbit anti-TGF $\beta 3$ (1:100, Abcam International). For the negative controls, ChromPure non-specific rabbit IgGs (Jackson Immuno Research Laboratories, Inc., West Grove, PA, USA) were used at the same concentration and sections were also incubated with secondary antibodies in the absence of primary antibodies. Secondary antibodies used for detection were biotinylated goat anti-rabbit (1:200; Vector, Burlingame, CA, USA). Final visualization was achieved using Vectastain Elite ABC Kit (Vector). Counterstaining with Harris Hematoxylin (Sigma diagnostics) was carried out before slides were mounted with Cytoseal XYL (Ricard-Allan Scientific, Kalamazoo, MI, USA). Myometrial cells from each of the three tissue sets were observed on a Leica DMRXE microscope (Leica Microsystems, Richmond Hill, ON, Canada). A minimum of five fields were examined for each gestational day and uterine horn for each set of tissue, and representative tissue sections were photographed with Sony DXC-970 MD (Sony Ltd., Toronto, ON, Canada) 3CCD color video camera.

\section{Statistical analysis}

Gestational profiles were subjected to a one-way ANOVA followed by pairwise multiple comparison procedures (Student-Newman-Keuls method) to determine differences between groups. P4 (days 21, 22, and 23) and tubal-ligation data were analyzed by two-way ANOVA followed by pairwise multiple comparison procedures as described above. The day 24 P4 treated group was compared with the day 23 vehicle group using a $t$-test. RU486 results were compared with vehicle using a oneway ANOVA, where required the data were transformed by the appropriate method to obtain a normal distribution. Statistical analysis was carried out using SigmaStat version 2.01 (Jandel Corp., San Rafael, CA, USA) with the level of significance for comparison set at $P<0.05$.

\section{Results}

Figure 1 illustrates the expression of $\operatorname{Tgf} \beta 1-3$ gene throughout pregnancy and post partum. Relative abundance of the Tgf $\beta 1 \mathrm{mRNA}$ was significantly increased starting at mid-gestation $(3.01 \pm 0.21$-fold increase on day 12 vs NP, $P<0.05)$ and was maintained elevated until labor and post partum $(5.22 \pm 0.80$-fold increase on day $1 P P$ versus NP, $P<0.05)$. No significant changes were found for Tgf $\beta 2$ myometrial transcript levels across gestation $(P>0.05)$. In contrast, a dramatic bimodal change in Tgf $\beta 3$ mRNA abundance was observed throughout pregnancy. We detected a transient activation of myometrial Tgf $\beta 3$ gene expression on gestational days 14-15 (11.30 $\pm 1.30-$ and $12.36 \pm 1.91$-fold increase versus NP, $P<0.05)$, a subsequent decrease at late gestation $(6.92 \pm 0.96$-fold increase on day 19 versus $N P$, $P<0.05)$, and a second dramatic increase at labor (45.31 \pm 8.73 -fold increase on day 23 versus NP, $P<0.05)$. During post partum involution Tgf $\beta 3$ transcript levels quickly decreased $(8.37 \pm 1.84$-fold increase on $1 \mathrm{PP}$ versus NP, $P<0.05)$. We applied immunoblotting technique to analyze if protein expression of TGF $\beta 1$ and TGF $\beta 3$ reflects their gene expression. As expected from the mRNA data, the expression of TGF $\beta 1$ and TGF $\beta 3$ proteins started increasing from mid-gestation $(P<0.05$ for day 17 versus $N P)$, was further up-regulated at late gestation and during labor (three- to fourfold increase on days 21-23 versus NP for TGF $\beta 1$ and TGF $\beta 3$ proteins, $P<0.05$; Fig. 2) and decreased thereafter. From these observations, it appears that the expression of TGF $\beta 1$ and TGF $\beta 3$ in rat myometrium was clearly dependent on gestational age.

We also studied the temporal and spatial distribution of TGF $\beta 3$ protein in the myometrium across gestation (Fig. 3). According to our observation, the TGF $\beta 3$ staining in the rat myometrium was significantly altered during pregnancy. Immunostaining of TGF $\beta 3$ in uterine smooth muscle of non-pregnant and early pregnant (day 6) animals was extremely weak. However, starting from day 15 the immunoreactivity of the rat myometrium 

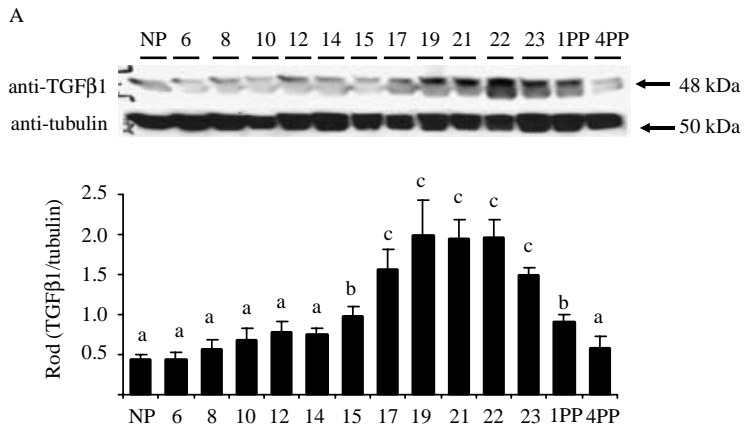

B
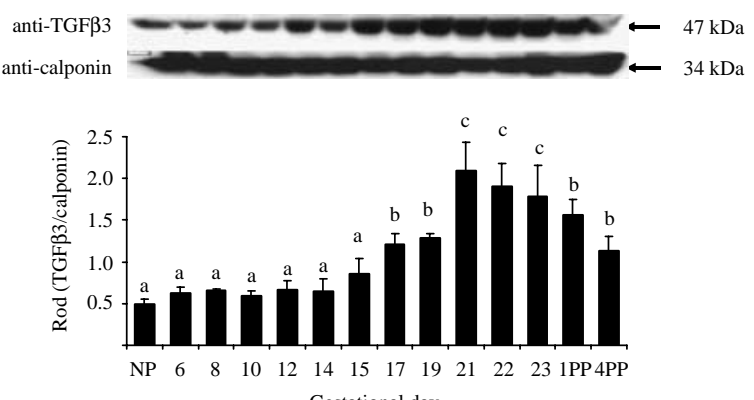

Gestational day

Figure 2 The effect of gestational age on the expression of TGF $\beta 1$ (A) and TGF $\beta 3$ (B) proteins in the pregnant rat myometrium.

Representative western blots and densitometric analysis of TGF $\beta 1$ and TGF $\beta 3$ protein levels throughout normal gestation and post partum. TGF $\beta 1$ and TGF $\beta 3$ protein expression levels were normalized to $\alpha$-tubulin (A) or calponin (B). Bar graphs showing the mean \pm s.E.M. $\operatorname{ROD}(n=3-4$ at each time point). Data labeled with different letters are significantly different from each other $(P<0.05)$.

increased dramatically (Fig. 3). Consistent with our gene and protein expression results the most intense staining was found in laboring samples. In addition, we detected more intense TGF $\beta 3$ immunostaining at late gestation in the circular myometrial layer when compared with the longitudinal myometrial layer (Fig. 3). TGF $\beta 3$ protein was always detected in the cytoplasm of myometrial SMCs and this spatial distribution was similar in both uterine muscle layers.

P4 is the major hormone of pregnancy in the rat. In our study, artificial maintenance of elevated P4 levels at late gestation (from day 20 to day 23) by daily injections of hormone caused a failure to initiate labor. We showed before that this treatment prevented the increase in the expression of CAPs, AP-1, and ECM genes in the rat myometrium (Piersanti \& Lye 1995, Shynlova et al. 2004). We have now shown that the administration of $P 4$ also prevented the increase of Tgf 33 mRNA levels at term when compared with vehicle-treated animals (Fig. 4A). Tgfß3 gene remained low in myometrium of P4-treated rats on gestational day 22, day 23 (labor), and day 24 ( 1 day after normal delivery) when compared with controls $(P<0.05)$. On the contrary, treatment of pregnant rats with the $\mathrm{P} 4$ receptor antagonist RU486 on day 19 caused the onset of preterm labor within $24 \mathrm{~h}$ and
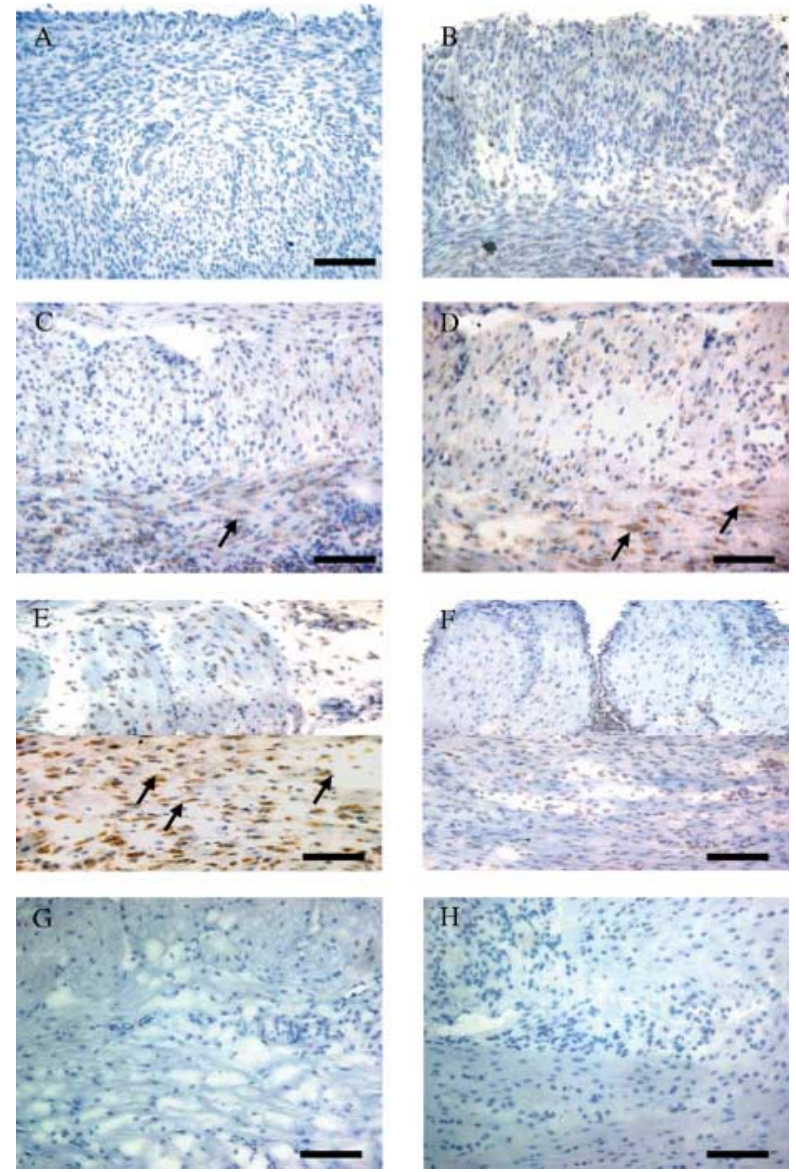

Figure 3 TGF $\beta 3$ immunolocalization in pregnant rat myometria during gestation. Immunohistochemical examination was performed on sections of uterus from non-pregnant (NP) (A), 6 days (B), 15 days (C), 17 days pregnant (D), laboring (day 23) (E), and 1 day post partum (F) animals. Expression of TGF $\beta 3$ in circular myometrial layers increased significantly during late gestation ( $\mathrm{C}-\mathrm{E}$, arrows). Relatively weak immunostaining was present in longitudinal myometrial layers (C-E). The lack of immunostaining after incubation of myometrial tissue with non-specific rabbit lgGs on gestational day $14(\mathrm{G})$ or with anti-rabbit secondary antibodies in the absence of primary antibody on labor (day 23) is shown in $\mathrm{H}$. Magnification, $200 \times$; scale bar $A-E=50 \mu \mathrm{m}$.

a 3.6-fold increase in Tgf $\beta 3$ gene expression $(P<0.05$, Fig. 4B). These results demonstrated that decreased $\mathrm{P} 4$ signaling during late pregnancy caused by RU486 led to Tgf $\beta 3$ gene induction, whereas maintenance of high plasma P4 levels prevented this increase.

Since TGF $\beta 1$ and TGF $\beta 3$ protein expression increased specifically at the second half of gestation when mechanical stretch of uterine walls imposed by growing fetuses was apparent, we decided to study $\operatorname{Tg} \beta 33$ gene and protein expression using the unilaterally pregnant rat model (Fig. 5). This model enables us to distinguish the effects of endocrine and mechanical stimuli, given that both gravid and empty horns were subjected to the same hormonal environment. Tgf 1 mRNA levels were not statistically different between empty and gravid horns (data not shown). We found that Tgf $\beta 3$ gene expression in 


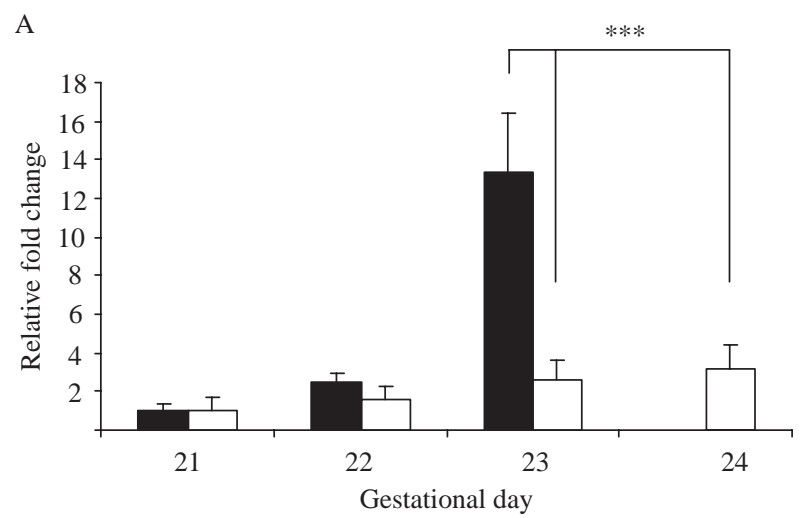

B

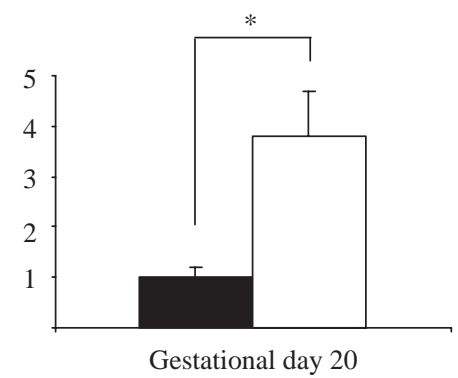

Figure 4 The effects of progesterone (A) and RU486 (B) on myometrial TGF $\beta 3$ expression. Real-time PCR analysis of TGF $\beta 3$ mRNA levels in pregnant rat myometrium during progesterone-delayed (A) and RU486induced preterm (B) labor normalized versus $18 \mathrm{~S}$ mRNA and expressed in fold change relative to a vehicle day 21 (A) or day 20 (B) samples. Shown are vehicle (black bars) and P4- or RU486-treated (white bars) samples. Values represent mean \pm s.D. ( $n=4$ at each time point). A significant difference is indicated by $* P<0.05$ or $* * * P<0.001$.

the empty horn was very low throughout gestation. In contrast, Tgf $\beta 3$ transcript levels were dramatically increased in the gravid uterine horns, showing a profile similar to that of normal pregnant animals. Relative quantification indicated a transient induction of $\operatorname{Tgf} \beta 3$

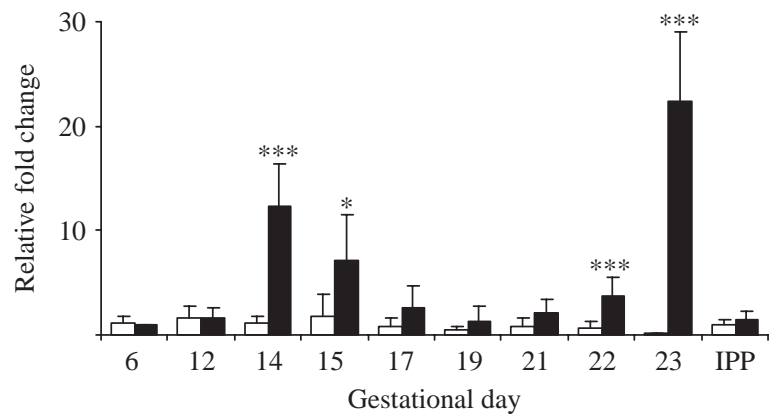

Figure 5 Expression of $T G F \beta 3$ gene in the myometrium of unilaterally pregnant rats during gestation. mRNA levels were analyzed on the indicated days of gestation by real-time PCR using specific primers (see Fig. 1). TGF 33 gene expression levels in empty (white bars) and gravid (black bars) were normalized to $18 \mathrm{~S}$ mRNAs and expressed in fold changes relative to a day 6 gravid sample. The bars represent mean \pm s.D. ( $n=4$ at each time point). A significant difference between gravid and empty horn of the same gestational day is indicated by ${ }^{*} P<0.05$ or ${ }^{* * *} P<0.001$. gene in the gravid horn at mid-pregnancy (12.4-fold increase on day 14 when compared with day 6) and at term (22.4-fold increase on day $23 \mathrm{~L}$ when compared with day 6; Fig. 5). This increase in Tgfß3 mRNA of the gravid horn was statistically different from the corresponding empty horn (two-way ANOVA, $P<0.05$ ). We also found a dramatic increase in TGF $\beta 3$ protein immunoreactivity in the gravid horns of unilaterally pregnant rats on late gestation (Fig. 6A, C and E) when compared with their pairing empty horns (Fig. 6B, D and F).

\section{Discussion}

We have previously reported that the myometrium undergoes gradual changes in phenotype throughout gestation. These stages are characterized by an early proliferative phase, an intermediate phase of cellular hypertrophy and matrix elaboration, and the final contractile phase (Shynlova et al. 2006). We proposed that phenotypic modulation of uterine myocytes is the result of integration of endocrine signals and mechanical stimulation of the uterus by the growing fetus. We have
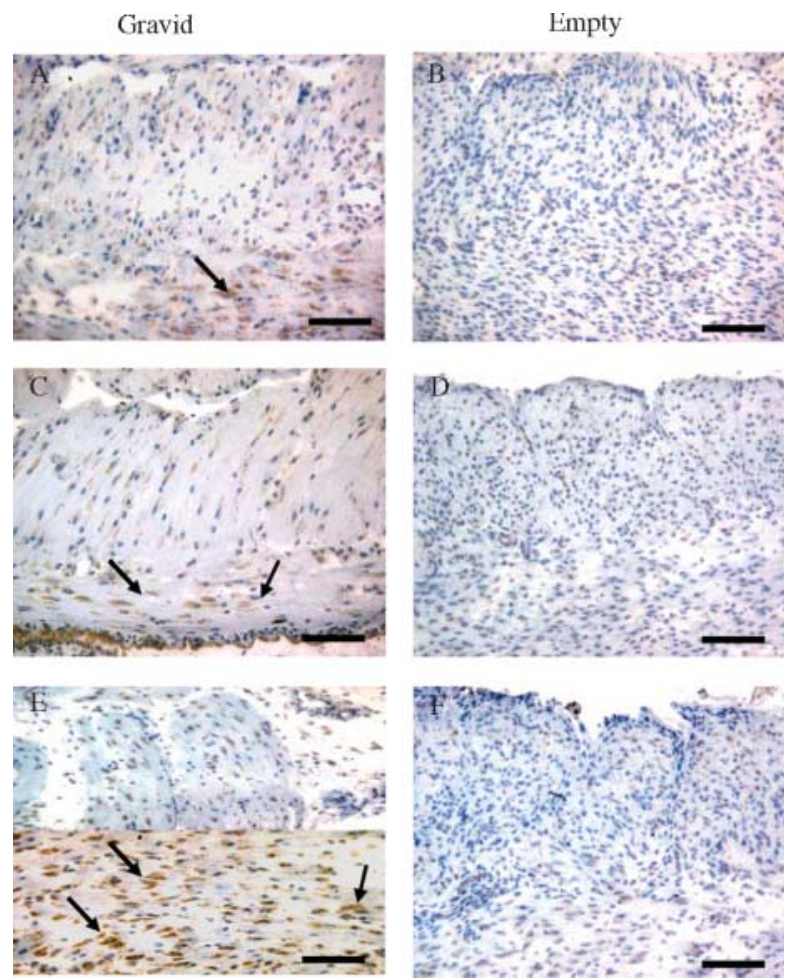

Figure 6 TGF $\beta 3$ localizes within the circular layer SMCs of the gravid myometrium from unilaterally pregnant rats. Uterine tissue was collected from empty and gravid horns of unilaterally pregnant rats on different gestational days, including day 17 (A and B), day 19 (C and D), and day 23 (E and F). Tissues were labeled with anti-TGF $\beta 3$ antibody and light microscopy images of cross-sections were collected. TGF $\beta 3$ localized mainly within the cytoplasm of circular muscle SMCs of the gravid uterine horn (arrows) and was much less abundant in the empty horn. No gestational changes in localization were observed. Magnification, $200 \times$; scale bar $A-H=50 \mu \mathrm{m}$. 
also demonstrated that these signals are important in regulating the onset of labor (Lye et al. 2001). In this report we showed that cytokines, specifically the TGF $\beta$ s, were (1) differentially expressed in the pregnant rat myometrium during specific phases of gestation and labor and (2) regulated by gravidity and ovarian hormones.

Numerous studies have shown that TGF $\beta$ s control a remarkable diversity of cellular functions, many of which are directly related to cell growth. We found that TGF $\beta$ mRNA and protein levels were low during the early phase of gestation when rat myometrial SMCs undergo hyperplasia, but increased during the synthetic phase when the proliferative activity of myometrial SMCs was substantially reduced. Consistent with our results, total TGF $\beta 1$ levels (Hatthachote et al. 1998) and TGF $\beta 3$ immunoreactive proteins (Kuscu et al. 2001) have been reported to be elevated in the pregnant human myometrium when compared with non-pregnant tissues. TGF $\beta 1$ is wellknown for its bimodal and dose-dependent effects on the growth of SMCs. Arici and colleagues demonstrated that low concentrations of TGF $\beta 1$ stimulate cell proliferation in leiomyoma (Arici \& Sozen 2003) and vascular cells (Battegay et al. 1990), while these stimulatory effects disappear at high TGF $\beta 1$ concentrations. It has been also shown that increased TGF $\beta 1$ gene expression induced by angiotensin II led to de novo protein synthesis in cultured vascular SMC (Koibuchi et al. 1993). New protein synthesis is a property of hypertrophic cells. We have previously documented myometrial hypertrophic growth during the second part of gestation (Shynlova et al. 2006). Our finding that TGF $\beta 1$ and TGF $\beta 3$ expression was induced during that specific time period raises the possibility that TGF $\beta$ s may support cellular hypertrophy in late pregnant uterus.

Interestingly, we observed two periods of transient myometrial induction of TGF 33 gene during rat gestation. The first increase in TGF $\beta 3$ gene expression occurred at mid-gestation (around day 14). As was shown before (Reynolds 1949) at that time fetal growth mediates an acute stretch of the uterine walls creating a transient hypoxemia of myometrial SMCs. We have previously shown that at this time there is a transient activation of the stress-induced (intrinsic) apoptotic pathway in the myometrium, a characteristic signal that we believe stops myometrial proliferative activity and promotes smooth muscle differentiation to a synthetic and later to a contractile phenotype (Shynlova et al. 2006). Interestingly, we found that the expression of hypoxia-induced transcription factor $(\mathrm{HiF}-1 \alpha)$ gene was up-regulated in the rat myometrium around day 14 of gestation and later at term, supporting the occurrence of two periods of hypoxia during gestation (Shynlova, Lye, unpublished). It has been shown in human placental explants that TGF $\beta 3$ expression correlates closely with the expression of HiF-1 $\alpha$ (Caniggia et al. 1999, 2000). In addition, HiF- $1 \alpha$ has been shown to directly regulate
TGF 33 gene expression in mouse trophoblast cells in vitro (Schaffer et al. 2003). Taken together, we suggest that the activation of $T G F \beta 3$ gene expression at mid- and late gestation is likely mediated by HiF-1 $\alpha$. It is also plausible that a similar molecular mechanism (mechanical stretch imposed by growing fetuses on myometrial SMCs) is responsible for the second period of TGF 33 gene induction in the rat myometrium before and during parturition. A number of in vitro studies have shown up-regulation of TGF $\beta$ by mechanical stretch in a variety of cell types such as vascular SMCs (Li et al. 1998), intestinal SMCs (Gutierrez \& Perr 1999), pulmonary arterial SMCs (Mata-Greenwood et al. 2005), and cardiomyoctyes (van Wamel et al. 2001). These data correspond well with our in vivo studies using the unilaterally pregnant rats where we demonstrated that $T G F \beta 3$ gene and protein expression was induced specifically in the gravid horns but not in the empty horns of late pregnant and laboring animals. Our results are further supported by a study using a similar experimental approach in which mRNA and protein expression of components of the TGF $\beta$-signaling axis are up-regulated by a stretch in the unilateral ureteric obstruction model in fetal sheep (Yang et al. 2001).

Furthermore, we found a difference in spatial distribution of TGF $\beta 3$ protein in a gravid horn; the circular myometrial layer showed more intense immunoreactivity than the longitudinal. Our previous studies have reported that the circular layer of the myometrium is more responsive to mechanical stretch than longitudinal based on the fact that the expression of the connexin43 (Doualla-Bell et al. 1995; a putative CAP gene) and $\gamma$-actin (Shynlova et al. 2005; a component of SM contractile apparatus) were increased in uterine circular muscle at late gestation. Others have also reported different responses to stretch, nor-adrenaline, and estrogen stimulation in circular versus longitudinal muscle (Matsumoto 1980, Doualla-Bell et al. 1995). This suggests that the two myometrial layers play different roles in labor contractions. The circular muscle primarily contracts rhythmically, while the longitudinal layer shortens the uterus upon expulsion of each fetus. We believe that stretch-induced activation of TGF $\beta$ signaling in the circular myometrial layer is one of the factors preparing the myometrium for labor. In other independent studies using cultured vascular SMCs, mechanical stretch not only stimulated TGF $\beta$ mRNA expression in a time- and elongation-dependent manner, but also up-regulated expression of type I and type IV collagen, and fibronectin genes, which was largely inhibited by addition of neutralizing antibody against TGF $\beta$ (Li et al. 1998, Joki et al. 2000). TGF $\beta 3$ treatment was also found to stimulate fibronectin expression in human cultured leiomyoma cells (Arici \& Sozen 2000). We have reported earlier that expression of fibronectin, as well as major components of basement membrane, namely type IV collagen and laminin, are dramatically 
up-regulated prior to and during labor in rats (Shynlova et al. 2004). Thus, the parallel increase of TGF $\beta 3$ and ECM components at late gestation suggests that TGF $\beta 3$ may mediate ECM induction, providing the mechanism to anchor hypertrophied uterine myocytes in order to produce coordinated, forceful labor contractions.

It has been shown in vitro that the TGF $\beta$-signaling system can be regulated by ovarian hormones in human myometrial cells (Chegini et al. 1996, Awad et al. 1997). In the non-pregnant ovariectomized mouse uterus, the expression of TGF $\beta$ can be transiently increased by the in vivo injection of estrogen (Das et al. 1992). In the present study we found a negative correlation between plasma P4 levels and the expression of TGF $\beta 3$ at late pregnancy, suggesting additional hormonal regulation of this gene. We speculate that the decrease in P4 levels, followed by an increase in estrogen plasma levels and mechanical stimulation of myometrium are all responsible for the activation of TGF $\beta 3$ at term.

To date, the physiological role of TGF $\beta$ s in preparing the myometrium for labor is not fully understood. Among the three TGF $\beta$ isoforms we studied, TGF $\beta 1$ and TGF $\beta 3$ genes show significant changes across gestation. We suggest that at mid-gestation TGF $\beta 3$ may influence the transition from proliferative and synthetic myometrial phenotypes. We also suggest that at late gestation both TGF $\beta 1$ and TGF $\beta 3$ proteins (1) support myometrial cellular hypertrophy and (2) play a role in the preparation of myometrium for labor contractions. Our results support and expand the understanding of myometrial phenotypic modulation during pregnancy and demonstrate a significant role for members of the TGF $\beta$ family in this process.

\section{Acknowledgements}

This study was supported by a grant from the CIHR. The authors declare that there is no conflict of interest that would prejudice the impartiality of this scientific work.

\section{References}

Arici A \& Sozen I 2000 Transforming growth factor- $\beta 3$ is expressed at high levels in leiomyoma where it stimulates fibronectin expression and cell proliferation. Fertility and Sterility 73 1006-1011.

Arici A \& Sozen I 2003 Expression, menstrual cycle-dependent activation, and bimodal mitogenic effect of transforming growth factor- $\beta 1$ in human myometrium and leiomyoma. American Journal of Obstetrics and Gynecology 188 76-83.

Attisano L \& Wrana JL 2002 Signal transduction by the TGF- $\beta$ superfamily. Science 296 1646-1647.

Awad SS, Lamb HK, Morgan JM, Dunlop W \& Gillespie JI 1997 Differential expression of ryanodine receptor RyR2 mRNA in the non-pregnant and pregnant human myometrium. Biochemical Journal 322 777-783.

Barnard JA, Lyons RM \& Moses HL 1990 The cell biology of transforming growth factor $\beta$. Biochimica et Biophysica Acta 1032 79-87.
Battegay EJ, Raines EW, Seifert RA, Bowen-Pope DF \& Ross R 1990 TGF- $\beta$ induces bimodal proliferation of connective tissue cells via complex control of an autocrine PDGF loop. Cell 63 515-524.

Caniggia I, Grisaru-Gravnosky S, Kuliszewsky M, Post M \& Lye SJ 1999 Inhibition of TGF- $\beta 3$ restores the invasive capability of extravillous trophoblasts in preeclamptic pregnancies. Journal of Clinical Investigation 103 1641-1650.

Caniggia I, Mostachfi H, Winter J, Gassmann M, Lye SJ, Kuliszewski M \& Post M 2000 Hypoxia-inducible factor-1 mediates the biological effects of oxygen on human trophoblast differentiation through TGFbeta(3). Journal of Clinical Investigation 105 577-587.

Challis JRG 1994 Physiology of Reproduction, pp 185-1031, New York: Raven Press.

Chegini N, Zhao Y, Williams RS \& Flanders KC 1994 Human uterine tissue throughout the menstrual cycle expresses transforming growth factor-beta 1 (TGF beta 1) TGF beta 2, TGF beta 3, and TGF beta type II receptor messenger ribonucleic acid and protein and contains [125I]TGF beta 1-binding sites. Endocrinology 135 439-449.

Chegini N, Rong H, Dou Q, Kipersztok S \& Williams RS 1996 Gonadotropin-releasing hormone $(\mathrm{GnRH})$ and $\mathrm{GnRH}$ receptor gene expression in human myometrium and leiomyomata and the direct action of GnRH analogs on myometrial smooth muscle cells and interaction with ovarian steroids in vitro. Journal of Clinical Endocrinology and Metabolism 81 3215-3221.

Chegini N, Ma C, Davis J, Duff P \& Rosa C 1999 Differential expression of transforming growth factor-beta 1 and transforming growth factorbeta receptors in myometrium of women with failed induction of labor, no labor, and preterm labor. Journal of the Society for Gynecologic Investigation 6 258-263.

Das SK, Flanders KC, Andrews GK \& Dey SK 1992 Expression of transforming growth factor-beta isoforms (beta 2 and beta 3 ) in the mouse uterus: analysis of the periimplantation period and effects of ovarian steroids. Endocrinology 130 3459-3466.

Doualla-Bell F, Lye SJ, Labrie F \& Fortier MA 1995 Differential expression and regulation of connexin-43 and cell-cell coupling in myocytes from the circular and longitudinal layers of bovine myometrium. Endocrinology 136 5322-5328.

Goldenberg RL, Mercer BM, lams JD, Moawad AH, Meis PJ, Das A, McNellis D, Miodovnik M, Menard MK, Caritis SN, Thurnau GR \& Bottoms SF 1997 The preterm prediction study: patterns of cervicovaginal fetal fibronectin as predictors of spontaneous preterm delivery. National Institute of Child Health and Human Development Maternal-Fetal Medicine Units Network. American Journal of Obstetrics and Gynecology 177 8-12.

Graham CH \& Lala PK 1991 Mechanism of control of trophoblast invasion in situ. Journal of Cellular Physiology 148 228-234.

Graham CH, Lysiak JJ, McCrae KR \& Lala PK 1992 Localization of transforming growth factor-beta at the human fetal-maternal interface: role in trophoblast growth and differentiation. Biology of Reproduction 46 561-572.

Gutierrez JA \& Perr HA 1999 Mechanical stretch modulates TGF-beta1 and alpha1(I) collagen expression in fetal human intestinal smooth muscle cells. American Journal of Physiology 277 G1074-G1080.

Hatthachote P \& Gillespie JI 1999 Complex interactions between sex steroids and cytokines in the human pregnant myometrium: evidence for an autocrine signaling system at term. Endocrinology $1402533-2540$.

Hatthachote P, Morgan J, Dunlop W, Europe-Finner GN \& Gillespie JI 1998 Gestational changes in the levels of transforming growth factorbeta1 (TGFbeta1) and TGFbeta receptor types I and II in the human myometrium. Journal of Clinical Endocrinology and Metabolism 83 2987-2992.

Joki N, Kaname S, Hirakata M, Hori Y, Yamaguchi T, Fujita T, Katoh T \& Kurokawa K 2000 Tyrosine-kinase dependent TGF-beta and extracellular matrix expression by mechanical stretch in vascular smooth muscle cells. Hypertension Research 23 91-99.

Koibuchi Y, Lee WS, Gibbons GH \& Pratt RE 1993 Role of transforming growth factor-beta 1 in the cellular growth response to angiotensin II. Hypertension 21 1046-1050. 
Kuscu NK, Lacin S, Vatansever S, Yildirim Y, Var A, Uyanik BS \& Koyuncu F 2001 Immunolocalization of transforming growth factorbeta 3 in pregnant human myometrium. Acta Obstetricia et Gynecologica Scandinavica 80 1079-1083.

Lawrence DA 1996 Transforming growth factor-beta: a general review. European Cytokine Network 7 363-374.

Li Q, Muragaki Y, Hatamura I, Ueno H \& Ooshima A 1998 Stretchinduced collagen synthesis in cultured smooth muscle cells from rabbit aortic media and a possible involvement of angiotensin II and transforming growth factor-beta. Journal of Vascular Research 35 93-103.

Lye SJ, Mitchell J, Nashman N, Oldenhof A, Ou R, Shynlova O \& Langille L 2001 Role of mechanical signals in the onset of term and preterm labor. Frontiers of Hormone Research 27 165-178.

Ma C \& Chegini N 1999 Regulation of matrix metalloproteinases (MMPs) and their tissue inhibitors in human myometrial smooth muscle cells by TGF-beta1. Molecular Human Reproduction $\mathbf{5}$ 950-954.

Massague J, Attisano L \& Wrana JL 1994 The TGF-beta family and its composite receptors. Trends in Cell Biology 4 172-178.

Mata-Greenwood E, Grobe A, Kumar S, Noskina Y \& Black SM 2005 Cyclic stretch increases VEGF expression in pulmonary arterial smooth muscle cells via TGF-beta1 and reactive oxygen species: a requirement for $\mathrm{NAD}(\mathrm{P}) \mathrm{H}$ oxidase. American Journal of Physiology. Lung Cellular and Molecular Physiology 289 L288-L289.

Matsumoto J 1980 Changes of the contraction of the circular and longitudinal muscles of pregnant rat myometrium during pregnancy (author's translation). Nippon Sanka Fujinka Gakkai Zasshi 32 1749-1757.

Ou CW, Orsino A \& Lye SJ 1997 Expression of connexin-43 and connexin-26 in the rat myometrium during pregnancy and labor is differentially regulated by mechanical and hormonal signals. Endocrinology 138 5398-5407.

Ou CW, Chen ZQ, Qi S \& Lye SJ 1998 Increased expression of the rat myometrial oxytocin receptor messenger ribonucleic acid during labor requires both mechanical and hormonal signals. Biology of Reproduction 59 1055-1061.

Piersanti M \& Lye SJ 1995 Increase in messenger ribonucleic acid encoding the myometrial gap junction protein, connexin-43, requires protein synthesis and is associated with increased expression of the activator protein-1, c-fos. Endocrinology 136 3571-3578.

Reynolds SRM 1949 Patterns of uterine growth during pregnancy, Physiology of the Uterus, 2nd edn. pp 218-234, New York: Hoeber.

Romero R, Avila C, Brekus CA \& Morotti R 1991 The role of systemic and intrauterine infection in preterm parturition. Annals of the New York Academy of Sciences 622 355-375.
Romero R, Espinoza J, Goncalves LF, Kusanovic JP, Friel LA \& Nien JK 2006 Inflammation in preterm and term labour and delivery. Seminars in Fetal and Neonatal Medicine 11 317-326.

Schaffer L, Scheid A, Spielmann P, Breymann C, Zimmermann R, Meuli M, Gassmann M, Marti HH \& Wenger RH 2003 Oxygenregulated expression of TGF-beta 3, a growth factor involved in trophoblast differentiation. Placenta 24 941-950.

Schilling B \& Yeh J 2000 Transforming growth factor-beta(1), -beta(2), -beta(3) and their type I and II receptors in human term placenta. Gynecologic and Obstetric Investigation 50 19-23.

Shynlova O, Mitchell JA, Tsampalieros A, Langille BL \& Lye SJ 2004 Progesterone and gravidity differentially regulate expression of extracellular matrix components in the pregnant rat myometrium. Biology of Reproduction 70 986-992.

Shynlova O, Tsui P, Dorogin A, Chow M \& Lye SJ 2005 Expression and localization of alpha-smooth muscle and gamma-actins in the pregnant rat myometrium. Biology of Reproduction 73 773-780.

Shynlova O, Oldenhof A, Dorogin A, Xu Q, Mu J, Nashman N \& Lye SJ 2006 Myometrial apoptosis: activation of the caspase cascade in the pregnant rat myometrium at midgestation. Biology of Reproduction 74 839-849.

Vemuganti R, Dempsey RJ \& Bowen KK 2004 Inhibition of intercellular adhesion molecule- 1 protein expression by antisense oligonucleotides is neuroprotective after transient middle cerebral artery occlusion in rat. Stroke 35 179-184.

van Wamel AJ, Ruwhof C, van der Valk-Kokshoom LE, Schrier PI \& van der LA 2001 The role of angiotensin II, endothelin-1 and transforming growth factor-beta as autocrine/paracrine mediators of stretch-induced cardiomyocyte hypertrophy. Molecular and Cellular Biochemistry 218 113-124.

Williams SJ, White BG \& MacPhee DJ 2005 Expression of alpha5 integrin (Itga5) is elevated in the rat myometrium during late pregnancy and labor: implications for development of a mechanical syncytium. Biology of Reproduction 72 1114-1124.

Yang SP, Woolf AS, Quinn F \& Winyard PJ 2001 Deregulation of renal transforming growth factor-beta1 after experimental short-term ureteric obstruction in fetal sheep. American Journal of Pathology 159 109-117.

Received 3 January 2007

First decision 26 January 2007

Revised manuscript received 22 May 2007

Accepted 1 June 2007 